\title{
Arti Penting Jawaban Atas Gugatan Sebagai Upaya Mempertahankan Hak-Hak Tergugat
}

\author{
Ery Agus Priyono, Herni Widanarti ${ }^{1}$, Dharu Triasih ${ }^{2}$ \\ Fakultas Hukum Universitas Diponegoro \\ JL. Prof. Sudharto No. 1 Semarang, Jawa Tengah, 50275 \\ eryap@live.undip.ac.id
}

\begin{abstract}
Jawaban atas gugatan adalah satu tahapan dalam proses pemeriksaan perkara perdata dan dilakukan setelah gugatan dibacakan penggugat dalam persidangan. Jawaban atas gugatan penggugat merupakan upaya bagi tergugat untuk mempertahankan hakhaknya terhadap dalih dan dalil penggugat. Tidak jauh berbeda dengan membuat gugatan, bagaimana bentuk dan susunan dari jawaban gugatan dan eksepsi dalam perkara perdata tidak diatur oleh peraturan perundang-undangan, kecuali hanya disebutkan bahwa gugatan harus memenuhi syarat formal dan materil.
\end{abstract}

\section{PEMBAHASAN}

Contoh Jawaban atas Gugatan Pembagian Harta Gono Gini

Kasus Posisi :

Walter Bin Stuart (WBS) umur 56 tahun, agama Islam, pekeriaan KNIL bertempat tinggal di Jalan A. Yani blog G Nomor 25 Kota Salatiga, mengajukan gugatan pembagian harta gono gini kepada mantan isterinya, Ny. Cinta Cahyaning Binti Lukon (CCBL) , yang saat ini bertempat tinggal di Jalan Singosari Nomor 4 Rt.2 Rw.4, Kelurahan Jomblo, Kecamatan Candisari, Kota Semarang.

WBS dan CCBL menikah secara sah pada 7 November 1985 di Kantor Urusan Agama Kecamatan Batangan, Kabupaten Pati, sebagaimana termuat dalam Kutipan Akta Nikah Nomor: 320/05/XI/85, dan pernikahan tersebut putus karena perceraian berdasarkan Putusan Pengadilan Agama Semarang Nomor: 234/PdtG/2016/PA Semarang 17 Juii 2017.

Dalam Perkawinan di atas diperoleh harta gono gini berupa:

\footnotetext{
${ }^{1}$ Dosen Fakultas Hukum Universitas Diponegoro.

${ }^{2}$ Fakultas Hukum Universitas Semarang.
} 
Vol 2, No. (2019): Law, Development \& Justice Review, Mei 2019. e-ISSN: 2655-1942

a. Sebidang tanah tercantum dalam buku C No. 649 / SFPT Nomor: 331701401500230 Persil 091 kelas III luas $8.750 \mathrm{M}^{2}$ atas nama Karyono. Lokasi Desa Tlogo Tunggal Kecamatan Sumber Kabupaten Rembang, dengan batas:

Utara : Tasimin

Selatan : Kasmila Kliwon

Barat : Jalan raya

Timur : Lilis

b. Tiga (3) kavling tanah dengan luas $425 \mathrm{M}^{2}$ lokasi dusun Kebon Tanian desa Kali Kayen Kecamatan Ungaran Kabupaten Semarang;

c. Sebidang tanah luas $5.750 \mathrm{M}^{2}$ atas nama Wagiman dibuat untuk kavling menjadi 23 kavling;

d. Satu unit mobil suzuki katana tahun 1994, warna hitam, nomor polisi H 7049 TG senilai Rp 54.000.000,- (lima puluh empat juta rupiah;

e. Satu unit mobil Daiiiatsu Taruna tahun 2001, warna silver metalic, nomor polisi H 9175 NR senilai Rp 90.000.000.- (sembilan puluh juta rupiah);

f. Alat perabot rumah tangga yang diperoleh selarna pernikahan yang, ditaksir seluruhnya senilai Rp 25.000.000,- (dua puluh lima juta rupiah). Jumlah keseluruhan harta gono - gini antara Penggugat dan Tergugat ditaksir sejumlah Rp 1.737.000.000,- (satu miiiyar tujuh ratus tiga puluh juta rupiah).

Atas gugatan Penggugat (WBS), selanjutnya tergugat (CCBL) mengajukan jawaban atas dalih dan dalil WBS sebagai berikut:

Kepada Yth.

\section{Ketua Majelis Hakim Pengadilan Agama Semarang \\ Di tempat}

Assalamualaikum warahmatullaahi wabarakaatuh.

Dengan hormat,

Yang bertanda tangan di bawah ini: 
Vol 2, No. (2019): Law, Development \& Justice Review, Mei 2019. e-ISSN: 2655-1942

kami, Ibu Cinta Cahyaning Binti Lukon (CCBL), umur 51 tahun, agama Islam, pekerjaan ibu rumah tangga, bertempat tinggal di Jalan Singosari Nomor 4 Rt.2 Rw.4, Kelurahan Jomblo, Kecamatan Candisari, Kota Semarang, selanjutnya disebut Tergugat Konvensi/Penggugat Rekonvensi

Majelis Hakim yang semoga senantiasa dirahmati Allah Subhanahu wa Ta'ala

\section{Saudara Penggugat Konvensi/Tergugat Rekonvensi yang saya hormati}

Bahwa setelah membaca dengan cermat dan memahami maksud dari gugatan pembagian harta gono gini yang diajukan oleh Penggugat Konvensi/Tergugat Rekonvensi dengan ini Tergugat Konvensi/Penggugat Rekonvensi hendak mengajukan tanggapan, sanggahan, jawaban atas Gugatan Penggugat Konvensi/Tergugat Rekonvensi, sebagai berikut:

\section{DALAM KONVENSI}

Bahwa Tergugat Konvensi/Penggugat Rekonvensi menolak seluruh dalil-dalil dan hal-hal lain yang diajukan Penggugat Konvensi/Tergugat Rekonvensi dalam gugatannya ini kecuali terhadap hal-hal yang diakui secara tegas dan terang tentang kebenarannya.

1. Benar, bahwa Penggugat Konvensi/Tergugat Rekonvensi dengan Tergugat Konvensi/Penggugat Rekonvensi telah melangsungkan pernikahan yang sah pada 7 November 1985 di kantor urusan agama kecamatan Batangan kabupatem Pati sesuai yang termuat dalam Kutipan Akta Nikah Nomor: 320/05/05/XI/85;

2. Benar bahwa perkawinan antara Penggugat Konvensi/Tergugat Rekonvensi dengan Tergugat Konvensi/Penggugat Rekonvensi telah putus karena perceraian, berdasarkan Putusan Pengadilan Agama Semarang Nomor: 234/pdt.G/2016/PA Semarang 17 Juli 2017;

3. Benar, bahwa antara Penggugat Konvensi/Tergugat Rekonvensi/ dengan Tergugat Konvensi/Penggugat Rekonvensi tidak mengajukan upaya hukum atas putusan pengadilan agama Semarang, sehingga putusan tersebut telat mempunyai kekuatan hukum tetap (inkracht van gewisjde) dan telah di keluarkan Akta Cerai Nomor: 1451/AC/2017/PA.Smg; 
Vol 2, No. (2019): Law, Development \& Justice Review, Mei 2019. e-ISSN: 2655-1942

4. Benar, bahwa dengan telah putusnya perkawinan antara Penggugat Konvensi/Tergugat Rekonvensi dengan Terggugat Konvensi/Penggugat Rekonvensi pembagian harta gono gini dapat dilaksanakan;

5. Benar, bahwa Penggugat Konvensi/Tergugat Rekonvensi dengan Tergugat Konvensi/Penggugat Rekonvensi selama perkawinan memperoleh harta bersama berupa:

a. sebidang tanah tercantum dalam buku Nomor: 649/SPPT Nomor: 337014015230 Persil 091 Kelas III luas 8750m² atas nama Karyono lokasi Desa Tlogotunggal kecamatan sumber Kabupaten Rembang dengan batas:

Utara : Tasimin

Selatan : Kasmila Kliwon

Barat : Jalan raya

Timur $\quad$ : Lilis

b. 3 kavling tanah dengan luas $425 \mathrm{~m}^{2}$ lokasi dusun kebun taman Desa Kalikayen Kecamatan Ungaran Kabupaten Semarang;

c. Benar, bahwa Penggugat Konvensi/Tergugat Rekonvensi dan Tergugat Konvensi/Penggugat Rekonvensi mempunyai sebidang tanah seluas $5.750 \mathrm{~m}^{2}$ atas nama Wagiman yang dibuat kavling, AKAN TETAPI tanah tersebut sudah dijual sejak 2009 untuk kebutuhan keluarga semasa Penggugat Konvensi/Tergugat Rekonvensi dan Tergugat Konvensi/Penggugat Rekonvensi masih ada ikatan perkawinan yang sah;

d. Benar, bahwa Penggugat Konvensi/Tergugat Rekonvensi dan Tergugat Konvensi/Penggugat Rekonvensi mempunyai 1 unit mobil suzuki cary th 1994 warna hitam Nomor Polisi H 7904 GT senilai Rp. 54.000.000, AKAN TETAPI mobil tersebut sudah dijual ketika Penggugat Konvensi/Tergugat Rekonvensi dan Tergugat Konvensi/Penggugat Rekonvensi masih terikat perkawinan yang sah, dan hasil Penjualan tersebut digunakan untuk biaya sekolah dan keluarga, karena Penggugat Konvensi/Tergugat Rekonvensi sudah tidak memberi nafkah ke keluarga sama sekali sejak tahun 2012. Sedangkan ketika itu anak kedua sedang menempuh kuliah kedokteran, dan anak ke-3 sekolah SMP, sedangkan Saya tidak berpenghasilan. Mobil tersebut juga dibeli secara kredit sehingga pembayaran angsuran menggunakan uang hasil penjualan tanah sebagaimana yang dimaksud poin 
Vol 2, No. (2019): Law, Development \& Justice Review, Mei 2019. e-ISSN: 2655-1942

sebelumnya. Dan ketika itu, Penggugat Konvensi/Tergugat Rekonvensi hanya menerima gaji Rp. 2.000.000.- (dua juta rupiah);

e. Benar bahwa Penggugat Konvensi/Tergugat Rekonvensi dan Tergugat Konvensi/Penggugat Rekonvensi mempunyai 1 unit mobil Dihatsu Taruna tahun 2001 warna Merah Maron, Nomor Polisi H 7917 HR, AKAN TETAPI mobil tersebut sudah dijual sekitar 2015 ketika Penggugat Konvensi/Tergugat Rekonvensi dan Tergugat Konvensi/Penggugat Rekonvensi maslh ada ikatan perkawinan;

f. Bahwa Untuk perabot rumah tangga, Penggugat Konvensi/Tergugat Rekonvensi sudah terlebih dahulu menjual perabot yang ada di rumah dinas sehingga yang ada di rumah sekarang tinggal bagian Tergugat Konvensi/Penggugat Rekonvensi, untuk nominal tidak benar jika Rp. 25.000.000.- (dua puluh lima juta rupiah);

6. Tidak benar jika sebelum dan sesudah perkawinan antara Penggugat Konvensi/Tergugat Rekonvensi dan Tergugat Konvensi/Penggugat Rekonvensi tidak ada perjanjian pembagian harta bersama karena kenyataannya Penggugat Konvensi/Tergugat Rekonvensi pernah membuat perjanjian di atas materai dengan kesadarannya tanpa ada tekanan;

7. Benar adanya harta bersama yang tercantum dalam poin $5 a$ dan $5 b$ sampai saat ini langsung atau tidak langsung dalam penguasaan Tergugat Konvensi/Penggugat Rekonvensi;

8. Untuk harta bersama yang tercantum $5 a$ dan $5 b$ Saya sebagai Tergugat Konvensi/Penggugat Rekonvensi menyerahkan sepenuhnya kepada undang-undang yang berlaku sesuai norma hukum yang berlaku.

\section{DALAM REKONVENSI}

1. Bahwa terhadap hal-hal yang telah dikemukakan sebagai jawaban tergugat Konvensi dalam konvensi merupakan bagian yang tidak dapat dipisahkan dengan rekonvensi yang merupakan satu kesatuan yang utuh.

2. Benar, bahwa Penggugat Konvensi/Tergugat Rekonvensi dengan Tergugat Konvensi/Penggugat Rekonvensi telah melangsungkan pernikahan yang sah pada 7 
Vol 2, No. (2019): Law, Development \& Justice Review, Mei 2019. e-ISSN: 2655-1942

November 1985 di Kantor Urusan Agama Kecamatan Batangan kabupatem Pati sesuai yang termuat dalam Kutipan Akta Nikah Nomor: 320/05/05/XI/85;

3. Benar bahwa perkawinan antara Penggugat Konvensi/Tergugat Rekonvensi dengan Tergugat Konvensi/Penggugat Rekonvensi telah putus karena perceraian, berdasarkan Putusan Pengadilan Agama Semarang Nomor: 234/pdt.G/2016/PA Semarang 17 Juli 2017;

4. Benar, bahwa antara Penggugat Konvensi/Tergugat Konvensi dengan Tergugat Konvensi/Penggugat Rekonvensi tidak mengajukan upaya hukum atas putusan pengadilan agama Semarang, sehingga putusan tersebut telat mempunyai kekuatan hukum tetap (inkracht van gewisjde) dan telah di keluarkan Akta Cerai Nomor: 1451/AC/2017/PA.Smg;

5. Bahwa dalih Penggugat Konvensi/Tergugat Rekonvensi pada angka 5 huruf, $c, d$, dan e, adalah tidak benar karena harta bersama sebagaimana tersebut dalam angka 5 huruf $c$, d, dan e TELAH DIJUAL ketika Penggugat Konvensi/Tergugat Rekonvensi dan Tergugat Konvensi/Penggugat Rekonvensi masih terikat dalam perkawinan yang sah;

6. Bahwa hingga saat ini harta bersama yang tersimpan dalam buku tabungan ASABRI, Tabungan perumahan, dan tabungan koperasi dikuasai oleh Penggugat Konvensi/Tergugat Rekonvensi, yang sudah sepatutnya dan wajib menurut hukum dibagi 2 antara Penggugat Konvensi/Tergugat Rekonvensi dengan Tergugat Konvensi/Penggugat Rekonvensi, karena merupakan bagian dari harta bersama .

Maka berdasarkan hal-hal tersebut di atas, bersama dengan ini Tergugat konvensi/Penggugat Rekonvensi mohon dengan hormat kepada Majelis hakim yang memeriksa dan memutuskan perkara saat ini berkenan memutus perkara ini dengan menyatakan sebagai berikut:

Dalam Konvensi

1. Menyatakan menolak gugatan Penggugat Konvensi untuk seluruhnya atau setidak-tidaknya menyatakan gugatan Penggugat tidak dapat diterima sepanjang berkenaan dengan Tergugat Konvensi;

2. Menghukum Penggugat untuk membayar seluruh biaya perkara yang timbul dalam perkara ini. 
Vol 2, No. (2019): Law, Development \& Justice Review, Mei 2019. e-ISSN: 2655-1942

Dalam Rekonvensi

1. Mengabulkan gugatan Penggugat Rekonvensi untuk seluruhnya;

2. Memerintahkan kepada Penggugat Konvensi/Tergugat Rekonvensi dan Penggugat Rekonvensi/Tergugat Konvensi untuk membagi dua atas harta bersama yang masih ada kecuali seperangkat mebelair yang dikuasai Tetgugat Konvensi/Penggugat Rekonvensi;

3. Menghukum Penggugat Konvensi/Tergugat Rekonvensi membayar segala biaya perkara

4. Apabila Pengadilan berpendapat lain mohon agar memberikan putusan yang seadil-adilnya.

Demikian jawaban dalam Konvensi dan gugatan dalam Rekonvensi dan atas perhatian Majelis Hakim kami ucapkan banyak terima kasih.

wassalamualaikum warahmatullaahi wabarakaatuh.

Hormat kami, 